\title{
Plasma and Blood Volumes in Severely Malnourished Jamaican Children
}

\author{
G. A. O. ALLEYNE \\ From the Medical Research Council, Tropical Metabolism Research Unit, University of the West Indies, Mona, Jamaica
}

Oedema and expansion of the extracellular fluid are well recognized as a complication of malnutrition in adults (McCance, 1951) as well as in children (Waterlow, Cravioto, and Stephen, 1960). An increase in total body water has also been described (Srikantia and Gopalan, 1957; Schnieden, Hendrickse, and Haigh, 1958; Smith, 1960). In the course of investigations on the renal function of malnourished children, a severe reduction in glomerular filtration rate was found (author's observations), and it became necessary to establish that in the children studied there was no reduction in circulating plasma or blood volume to account for these changes. The results of these determinations are now described.

\section{Material and Methods}

Seven male malnourished children were studied as soon after admission as possible and at intervals during their hospital stay, while they were recovering from malnutrition.

In all cases, protein-calorie malnutrition was the primary illness, and the clinical picture corresponded to that described and reviewed by Waterlow et al. (1960). There were 4 children with, and 3 without oedema on admission. The treatment of these children was as set out by Garrow, Picou, and Waterlow (1962) and consisted essentially of graduated feeds, therapy of infection, administration of ferrous sulphate and folic acid orally and of potassium supplements to restore deficits which invariably occur in malnutrition (Garrow, 1965).

Plasma volume was determined by isotope dilution after the intravenous injection of ${ }^{131}$ I-labelled human serum albumin containing 1-2 $\mu \mathrm{c}$. A single sample of blood was withdrawn 10 minutes after the ${ }^{131} I$ injection and the plasma activity determined in a well type scintillation counter. The haematocrit was measured in a Hawksley micro-haematocrit centrifuge with capillary tubes. The blood volume was calculated as:

Plasma volume $\times 100$ $100-\mathrm{WBH}$ where WBH (whole body

Received November 8, 1965. haematocrit $)=$ corrected venous haematocrit $\times 0.91$ (Chaplin, Mollison, and Vetter, 1953). Plasma volumes were measured initially within 4 days of admission and at varying intervals until recovery.

\section{Results}

In every case there was a rise in the absolute plasma volume as the child recovered (Table). When expressed per kg. body weight, the plasma volume fell with recovery, and in Fig. 1 is shown the relation between plasma volume expressed as $\mathrm{ml} . / \mathrm{kg}$. body weight and the weight deficit. As the children recovered and approached their ideal weight, there was a fall in their plasma volume per kg. body weight. The mean plasma volume in the malnourished children was $62 \cdot 9 \mathrm{ml}$./kg. (range $42 \cdot 4$ $-76 \cdot 6$ ) and after recovery $49 \cdot 3 \mathrm{ml} . / \mathrm{kg}$. (range $44 \cdot 0$ $56 \cdot 6)$. The difference is significant $(p<0.05)$. The absolute blood volume also rose with recovery, but there is no significant difference between the

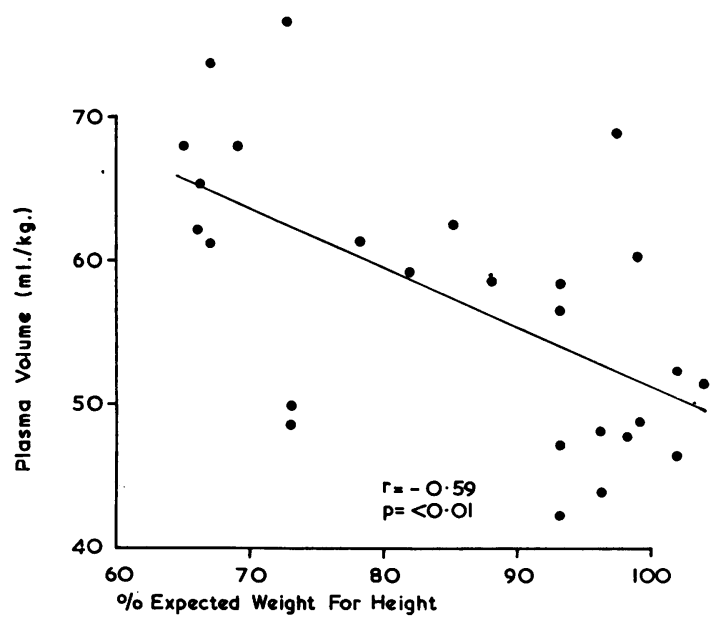

Fig. 1.-Plasma volumes in malnourished and recovering children related to their percentage expected weight for height $(y=-0.4 x+91 \cdot 4)$. 
TABLE

Absolute Plasma and Blood Volumes in the 7 Children

\begin{tabular}{|c|c|c|c|c|c|c|}
\hline Child & $\begin{array}{l}\text { Age on } \\
\text { Admission } \\
\text { (mth.) }\end{array}$ & $\begin{array}{l}\text { Days After } \\
\text { After } \\
\text { Admission }\end{array}$ & $\begin{array}{c}\text { Body Weight } \\
\text { (kg.) })^{\star}\end{array}$ & $\begin{array}{l}\text { Weight as \% of } \\
\text { Expected Weight } \\
\text { for Height }\end{array}$ & $\begin{array}{l}\text { Plasma } \\
\text { Volume } \\
\text { (ml.) }\end{array}$ & $\begin{array}{c}\text { Blood } \\
\text { Volume } \\
\text { (ml.) }\end{array}$ \\
\hline D.M. & 9 & $\begin{array}{r}1 \\
10 \\
35 \\
50\end{array}$ & $\begin{array}{c}8 \cdot 78 \\
(8 \cdot 12) \\
8 \cdot 12 \\
9 \cdot 35 \\
9 \cdot 50\end{array}$ & $\begin{array}{r}88 \cdot 3 \\
89 \cdot 9 \\
97 \cdot 2 \\
104 \cdot 0\end{array}$ & $\begin{array}{l}344 \\
383 \\
491 \\
442\end{array}$ & $\begin{array}{l}549 \\
581 \\
667 \\
596\end{array}$ \\
\hline L.N. & 14 & $\begin{array}{r}2 \\
12 \\
54 \\
109\end{array}$ & $\begin{array}{c}5 \cdot 80 \\
(5 \cdot 43) \\
5 \cdot 50 \\
7 \cdot 14 \\
9 \cdot 36\end{array}$ & $\begin{array}{l}65 \cdot 0 \\
65 \cdot 9 \\
81 \cdot 6 \\
96 \cdot 0\end{array}$ & $\begin{array}{l}369 \\
\\
358 \\
423 \\
412\end{array}$ & $\begin{array}{l}402 \\
511 \\
629 \\
639\end{array}$ \\
\hline J.G. & 15 & $\begin{array}{r}1 \\
12 \\
81 \\
\end{array}$ & $\begin{array}{c}7 \cdot 14 \\
(7 \cdot 02) \\
7 \cdot 02 \\
9 \cdot 62 \\
\end{array}$ & $\begin{array}{l}73 \cdot 1 \\
73 \cdot 1 \\
95 \cdot 7 \\
\end{array}$ & $\begin{array}{l}342 \\
350 \\
464 \\
\end{array}$ & $\begin{array}{l}482 \\
476 \\
700\end{array}$ \\
\hline H.G. & 8 & $\begin{array}{r}2 \\
14 \\
50\end{array}$ & $\begin{array}{c}4 \cdot 15 \\
(3 \cdot 90) \\
4 \cdot 46 \\
5 \cdot 68\end{array}$ & $\begin{array}{l}84 \cdot 8 \\
97 \cdot 0 \\
98 \cdot 8\end{array}$ & $\begin{array}{l}244 \\
309 \\
276\end{array}$ & $\begin{array}{l}324 \\
422 \\
399\end{array}$ \\
\hline S.M. & 18 & $\begin{array}{r}3 \\
11 \\
29 \\
129 \\
\end{array}$ & $\begin{array}{l}4 \cdot 65 \\
5 \cdot 00 \\
6 \cdot 05 \\
8 \cdot 74 \\
\end{array}$ & $\begin{array}{l}69 \cdot 4 \\
66 \cdot 7 \\
77 \cdot 6 \\
95 \cdot 5\end{array}$ & $\begin{array}{l}316 \\
306 \\
372 \\
419\end{array}$ & $\begin{array}{l}382 \\
421 \\
534 \\
632\end{array}$ \\
\hline J.F. & 11 & $\begin{array}{r}1 \\
12 \\
69 \\
118 \\
\end{array}$ & $\begin{array}{l}4 \cdot 50 \\
4 \cdot 60 \\
6 \cdot 62 \\
7 \cdot 94 \\
\end{array}$ & $\begin{array}{l}67 \cdot 2 \\
66 \cdot 2 \\
92 \cdot 6 \\
92 \cdot 9 \\
\end{array}$ & $\begin{array}{l}332 \\
286 \\
386 \\
449 \\
\end{array}$ & $\begin{array}{l}410 \\
393 \\
582 \\
659\end{array}$ \\
\hline A.W. & 9 & $\begin{array}{r}4 \\
47 \\
75 \\
123\end{array}$ & $\begin{array}{l}4 \cdot 32 \\
5 \cdot 54 \\
6 \cdot 65 \\
7 \cdot 86\end{array}$ & $\begin{array}{r}72 \cdot 6 \\
87 \cdot 9 \\
99 \cdot 3 \\
104 \cdot 1\end{array}$ & $\begin{array}{l}331 \\
324 \\
401 \\
422\end{array}$ & $\begin{array}{l}414 \\
451 \\
580 \\
620\end{array}$ \\
\hline
\end{tabular}

$\star$ The figures in brackets for the first 4 children represent the minimal weight after they had lost oedema.

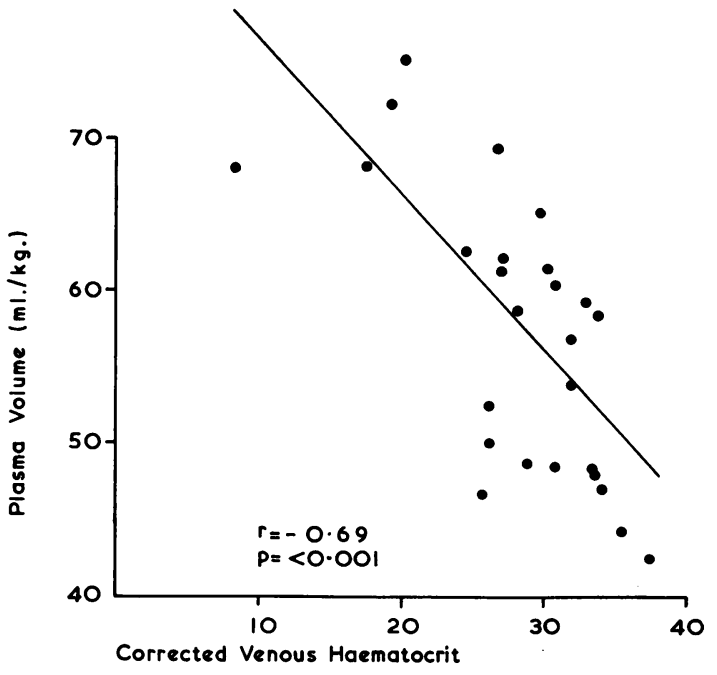

Fig. 2.-Relation of plasma volume to corrected venous haematocrit (peripheral venous haematocrit $\times 0.91$ ) $(y=-0.02 x+86 \cdot 06)$. blood volumes expressed as $\mathrm{ml} . / \mathrm{kg}$. body weight in the malnourished and recovered children. The mean values are $80 \cdot 4 \mathrm{ml} . / \mathrm{kg}$. $(67 \cdot 6-95 \cdot 8)$ for the malnourished children and $72 \cdot 6(62 \cdot 7-83 \cdot 0)$ for the recovered children $\mathrm{p}>0 \cdot 1$. The relationship of the plasma volume to the venous haematocrit is shown in Fig. 2. The falling plasma volume correlated with a rising venous haematocrit.

\section{Discussion}

The estimation of plasma volume by determining the activity in a sample of plasma taken 10 minutes after the injection of a suitable tracer assumes that there is rapid uniform mixing within the intravascular space. This has been shown in dogs by Wasserman and Mayerson (1951) who found almost identical activity in samples drawn from different sites. In addition, the relatively slow rate of disappearance of the label initially makes a single 10minute sample reliable enough for all practical purposes. It is appreciated that the method used here for measurement of blood volume is not ideal 
and it would have been preferable to measure red cell mass and plasma volume independently. The assumption also that the ratio of whole body haematocrit to peripheral venous haematocrit holds true for malnourished children was not validated in this study. Several workers have reported on the increased plasma volume occurring in malnutrition, irrespective of the methods used (Gollan, 1948; Gomez, Ramos Galván, Cravioto Muñóz, and Bienvenú, 1950; Cohen and Hansen, 1962; Picou, 1963). Gomez et al. (1950) used Evans Blue and found a mean value for plasma volume of $83 \mathrm{ml} . / \mathrm{kg}$. in malnourished children compared with $62 \mathrm{ml} . / \mathrm{kg}$. in normal subjects. These values are unaccountably much higher than those found in the present or any other study. They also showed that the increase in plasma volume per unit body weight could be related to the weight deficit.

Cohen and Hansen (1962) observed mean values of $61 \mathrm{ml} . / \mathrm{kg}$. and $51 \mathrm{ml} . / \mathrm{kg}$. for the malnourished and recovered children, respectively, and Picou (1963) obtained figures of $60 \mathrm{ml} . / \mathrm{kg}$. and $50 \mathrm{ml} . / \mathrm{kg}$. for malnourished and recovered children. These values are all strikingly close to the ones obtained in this study. The blood volume for recovered children $(72.6 \mathrm{ml} . / \mathrm{kg}$.) is also close to the $71.5 \mathrm{ml} . / \mathrm{kg}$. given by Russell (1949) for 64 normal children of similar ages to the ones studied here. Gomez et al. (1950) again had higher values than these for blood volume $-135 \mathrm{ml} . / \mathrm{kg}$. in malnourished and $105 \mathrm{ml} . /$ $\mathrm{kg}$. in normal children. Their finding of a statistically significant difference in blood volumes between malnourished and recovered children was not substantiated in the present study.

The concept that the increase in body water constitutes a response to the reduction in body solids (Smith, 1960) may well be applied to the blood. The plasma volume is closely related to the venous haematocrit, and with rising haematocrit there is a fall in plasma volume. Meanwhile there is no trend in blood volume changes. This seems to indicate that the blood behaves as other tissues and there is a compensatory increase in the liquid phase with decrease in the solid phase. This decrease of plasma volume with increasing haematocrit is not peculiar to malnutrition, but has been demonstrated previously in such conditions as pernicious anaemia (Gibson, 1939). Other attempts to explain the relative increase in plasma volume in malnutrition, e.g. increased aldosterone production, have not been substantiated. Indeed, Lurie and Jackson (1962) measured urinary aldosterone levels in kwashiorkor patients but could not demonstrate any significant increases.

\section{Summary}

Twenty-six determinations of plasma and blood volumes were done in 7 malnourished Jamaican children, on admission to hospital and as they recovered. There was a fall in plasma volume expressed per unit of body weight but no change in blood volume. There were significant correlations between the plasma volume changes, the weight deficit, and the venous haematocrit.

The author would like to express his appreciation to Dr. J. Garrow and Dr. D. Picou for their help, and to Professor J. C. Waterlow who gave advice and reviewed the manuscript.

\section{REFERENCES}

Chaplin, H., Jr., Mollison, P. L., and Vetter, H. (1953). The body venous hematocrit ratio: its constancy over a wide hematocrit range. f. clin. Invest., 32, 1309.

Cohen, S., and Hansen, J. D. L. (1962). Metabolism of albumin and $\gamma$-globulin in kwashiorkor. Clin. Sci., 23, 351.

Garrow, J. S. (1965). Total body-potassium in kwashiorkor and marasmus. Lancet, 2, 455.

, Picou, D., and Waterlow, J. C. (1962). The treatment and prognosis of infantile malnutrition in Jamaican children. W. Indian med. $\mathcal{F}$., 11, 217.

Gibson, J. G., II (1939). Clinical studies of the blood volume. VI. Changes in blood volume in pernicious anemia in relation to the hematopoietic response to intramuscular liver extract therapy f. clin. Invest., 18, 401.

Gollan, F. (1948). Blood and extracellular fluid studies in chronic malnutrition in infancy. ibid., 27, 352.

Gomez, F., Ramos Galván, R., Cravioto Muñóz, J., and Bienvenú, B. (1950). Estudios sobre el niño desnutrido. VII. El volumen sanguineo y el del plasma en el pre-escolar desnutrido. Bol. méd. Hosp. infant. (Méx), 7, 514.

Lurie, A. O., and Jackson, W. P. U. (1962). Aldosteronuria and the edema of kwashiorkor. Amer. F. clin. Nutr., 11, 115.

McCance, R. A. (1951). History, significance, and aetiology of hunger oedema. Spec. Rep. Ser. med. Res. Coun. (Lond.), 275, 21.

Picou, D. I. M. (1963). Protein metabolism in protein depleted infants. Ph.D. thesis, University of London.

Russell, S. J. M. (1949). Blood volume studies in healthy children. Arch. Dis. Childh., 24, 88.

Schnieden, H., Hendrickse, R. G., and Haigh, C. P. (1958). Studies in water metabolism in clinical and experimental malnutrition. Trans. roy. Soc. trop. Med. Hyg., 52, 169.

Smith, R. (1960). Total body water in malnourished infants. Clin. Sci., 19, 275.

Srikantia, S. G., and Gopalan, C. (1957). Validity of the urea method for estimating total body-water in malnutrition. Lancet, 2, 1037.

Wasserman, K., and Mayerson, H. S. (1951). Exchange of albumin between plasma and lymph. Amer F. Physiol., 165, 15.

Waterlow, J. C., Cravioto, J., and Stephen, J. M. L. (1960). Protein malnutrition in man. Advanc. Protein Chem., 15, 131. 